\title{
Water and Soil, Blood and Oil
}

\author{
Demarcating the Frontiers of Australia, Indonesia and Timor-Leste
}

\author{
David Dixon
}

This chapter explores frontiers as political and economic constructs, focusing on the contested borders and boundaries of Timor-Leste.* At its centre is a dispute about the maritime boundary between Timor-Leste and Australia in which access to hydrocarbon resources in the Timor Sea has been at stake. In 2018, Timor-Leste and Australia signed a Treaty 'to settle finally their maritime boundaries in the Timor Sea' (2018 Treaty). ${ }^{1}$ Despite considerable mutual self-congratulation, ${ }^{2}$ this treaty does not finalise the boundary (instead creating an anomalous and temporary enclave to accommodate Australia's economic interests). Nor does it deal conclusively with the crucial question of who should extract oil and gas or where processing should be carried out: it could not do so, for these decisions are ultimately not for nation states but for international corporations. To them, frontiers are less about pride and security than about opportunities and obstacles. This indicates a broader theme: borders and boundaries may be products not of the rational application of legal principles, but rather of political (often symbolic) concerns about sovereignty and of pragmatic, economic interests in resources allocated to states by frontier delineations.

* Acknowledgements: This paper is written in tribute to David Freestone, a friend and former colleague who has taught me much, not least the importance of academic integrity and commitment. As well as thanking David, I acknowledge Richard Barnes, Clinton Fernandes, Patrick Earle, José Ramos-Horta and the extraordinary people at La'o Hamutuk and TimorLeste's Marine Boundary Office. Thanks also to Grant Boyes and Geoscience Australia for the maps. None of these is responsible for anything herein.

1 Foreword to 2018 Treaty between Australia and the Democratic Republic of Timor-Leste establishing their Maritime Boundaries in the Timor Sea (2018 Treaty), [2019] ATS 16.

2 See comments by government representatives of Australia and Timor-Leste in 'Australia and Timor-Leste Sign Maritime Boundary Treaty' DFAT Press Release (7 March 2018), https:// www.foreignminister.gov.au/minister/julie-bishop/media-release/australia-and-timor-lestesign-maritime-boundary-treaty; accessed 30 September 2020. 
The maritime boundary dispute can only be properly understood in the broader context of relations between Australia, Timor-Leste and Indonesia. These relations have resulted in a border, the division of the island of Timor between Indonesia and (what is now) the Democratic Republic of Timor-Leste. This complex border - one line dividing the island from north to south and another enclosing a small enclave in north-west Timor ${ }^{3}$ - is a legacy of colonial occupation by the Dutch in the west of the island and by the Portuguese in the east. For the last quarter of the twentieth century, this border merely separated two Indonesian provinces. Soon after East Timor declared independence in the wake of its 1975 abandonment by post-colonial Portugal, Indonesia invaded, uniting the island until a heroic resistance movement led to multinational intervention in 1999 and restoration of independence - and the elevation of the border to the status, once again, of an international frontier.

Frontiers are of variable tangibility. Land borders are usually identifiable and impact upon living space. Maritime boundaries are nebulous and distant: they are the product of complex interactions involving physical features as well as legal and political compromises. ${ }^{4}$ They may differ in regard to the seabed and the water column above it. ${ }^{5}$ Even more amorphous are economic borders, established by trade or resource-sharing agreements. ${ }^{6}$ Then come the least distinct borders between truth and lies, between expediency and principle, between the past and the future, between cynicism and integrity, and between people whose lives count and those whose lives do not. In exploiting the uncertainty of maritime boundaries, Australia trod an unsteady path along the borders of the final type. Here, public opinion, in-country action and NGO activity are often juxtaposed with political deceit, arrogance and opportunism.

3 The Oecusse enclave is $8 \mathrm{o} \mathrm{km}$ from the bulk of Timor-Leste, which also includes the islands of Atauro and Jaco.

$4 \mathrm{~J}$ Nevins, 'Contesting the Boundaries of International Justice: State Countermapping and Offshore Resource Struggles between East Timor and Australia' (2004) 8o Economic Geography $1-22$.

5 There are sections of 'the central and northern Timor Sea where Australia has jurisdiction over the continental shelf ... and Indonesia has jurisdiction over the overlying water column': C Schofield, 'Minding the Gap: The Australia-East Timor Treaty on Certain Maritime Arrangements in the Timor Sea' (2007) 22 International Journal of Marine and Coastal Law 189-234, 193-194. On the consequences for people whose livelihood depended on fishing in the Timor Sea, see R Balint, Troubled Waters: Borders, Boundaries and Possession in the Timor Sea (Allen \& Unwin, 2005) 27-30, 97-102.

6 See D Ong, Chapter 4, this volume: 'Shared Responsibility or Institutional Accountability? Continuing Conceptual and Enforcement Issues for Grievance Mechanisms of Public and Private International Finance Institutions'. 
When Portugal's colonial regime ended, Indonesia decided that the borders enclosing what it saw as the anomaly of East Timor within the Indonesian archipelago should be abolished. Argument about Australia's complicity in the Indonesian invasion has continued ever since. On the most favourable account, Prime Minister Whitlam insisted that the East Timorese had a right to self-determination and that any Indonesian incorporation of Timor-Leste should be peaceful and consensual. Unfortunately, the Indonesian generals pushing President Soeharto for permission to engage heard only that Australia favoured incorporation, the first part of a notoriously ambivalent, indeed contradictory message. On a more critical reading, Australian references to self-determination (and indeed non-violence) were little more than windowdressing: the Australian Government - along with other allies, notably the United States - passively encouraged Indonesia to take East Timor, knowing that this would be done by force. ${ }^{7}$

Information about border crossings can be precious and perilous. A clear signal was given to Indonesia by Australia's failure to protest pre-invasion incursions by Indonesian forces, even when the largest of these included the slaughter at Balibo of five journalists (two Australians, two British and one New Zealander) to prevent them reporting on Indonesian forces crossing the border into East Timor. ${ }^{8}$ The Australian, British and New Zealand governments responded pusillanimously to the murder of their citizens. There was again no protest when another Australian journalist was murdered to stop him reporting on the border being breached conclusively, as Indonesian troops swept into Dili in December $1975 .{ }^{9}$

This began a period of terror, torture, starvation and displacement for the East Timorese in a hostile occupation which led to the deaths of some 200,000 people, i.e., one third of the population..$^{10}$ What the Indonesian army did must

7 J Dunn, Timor: A People Betrayed (ABC Books, 1996).

8 D Ball and H McDonald, Death in Balibo, Lies in Canberra (Allen \& Unwin, 200o); J Jolliffe, Cover-up: The Inside Story of the Balibo Five (Scribe, 20o1); B Saul, 'Prosecuting War Criminals at Balibo under Australian Law' (2009) 31 Sydney Law Review 83-120.

$9 \quad$ Ball and McDonald, above (n 8); Jolliffe above (n 8); A Barker, 'Justice Denied for "Sixth Balibo Journalist"' ABC News (11 June 2007), https://www.abc.net.au/news/2007-06-11/ justice-demanded-for-sixth-balibo-journalist/64952, accessed 3o September 2020.

10 Dunn, above (n 7); Commission for Reception, Truth and Reconciliation in East Timor (CAVR), Chega! The Report of the Commission for Reception, Truth and Reconciliation in Timor-Leste (CAVR, 2005); JG Taylor, 'East Timor: Counter-insurgency and Genocide' in R Gellately and B Kiernan (eds), The Specter of Genocide: Mass Murder in Historical Perspective (Cambridge University Press, 2003). 
be understood in relation to their responsibility for the massacre of up to one million of their (allegedly communist) compatriots in $1965^{-66}$. The rise of the leftist Fretelin in East Timor was a provocation to which the Indonesia army reacted with a savagery about which no-one who was aware of what happened in the previous decade could claim to be surprised. Geoffrey Robinson has shown that the United Kingdom, the United States and Australia not only knew about but 'facilitated and encouraged' mass murder in Indonesia." ${ }^{11}$ The Australian Prime Minister, Harold Holt, even thought that joking about it was appropriate. $^{12}$

The Indonesian government did what it could to prevent information about what was happening within East Timor crossing the border to international audiences. Australia cooperated by disrupting communications with the Timorese resistance. ${ }^{13}$ Meanwhile, the United States and the United Kingdom got on with selling military equipment to the Indonesian regime, including aircraft suited to ground attack and able to drop napalm. ${ }^{14}$ The United Nations Security Council twice called for Indonesian withdrawal. ${ }^{15}$ The General Assembly passed eight resolutions between 1975 and 1982 recognizing the rights of the East Timorese to self-determination and independence. Initially these called for Indonesian withdrawal, later shifting to weaker expressions of humanitarian concern. Shamefully, Australia voted in favour of only the first, subsequently abstaining or voting against later resolutions. The United Kingdom abstained throughout. The United States abstained from the first, then voted against all subsequent resolutions. ${ }^{16}$

International governmental opinion began to shift when indisputable evidence emerged of a massacre at a Dili cemetery in 1991 (which included the murder of a student from my university, Kamal Bamadhaj). Soeharto's resignation and economic problems in Indonesia provided the potential for a change

11 G Robinson, The Killing Season: A History of the Indonesian Massacres (Princeton University Press, 2018) 294.

12 Ibid 177. For conclusive evidence of the army's responsibility, see J Melvin, The Army and the Indonesian Genocide: Mechanics of Mass Murder (Routledge, 2018).

13 M Aarons, 'Appeasing Jakarta: Correspondence' (2001) 3 Quarterly Essay 66-71, 68-69; Ball and McDonald, above (n 8), 179-180.

14 M Phythian, The Politics of British Arms Sales since 1964 (Manchester University Press, 200o); P Dorking, 'Australia Knew about Indonesia's Napalm Plans in Timor Leste' Sydney Morning Herald (8 May 2015).

15 UN Security Council Resolutions S/RES/384 (1975) and S/RES/389 (1976).

16 The resolutions are available at https://etan.org/etun/genasRes.htm (accessed 1 July 2018), while the record of General Assembly votes is collated at https:/etan.org/etun/ UNvotes.htm (accessed 1 July 2018). 
of policy. Australian Prime Minister John Howard suggested a gradual move to self-determination for East Timor. ${ }^{17}$ This was expected to lead eventually to consensual legal incorporation into Indonesia on improved terms. However, Indonesian Prime Minister Habibe lost patience and called a referendum in 1999. Finally, given the power to decide their own future, the people of East Timor voted overwhelmingly for independence. The Indonesian military exacted a terrible revenge as it withdrew, executing a campaign of murder and destruction which left thousands dead and most of Timor-Leste's buildings and infrastructure in ruins. Having ignored warnings of what could happen, Australia belatedly led an international peace-keeping mission which provided the conditions for Timor-Leste's independence in 2002. ${ }^{18}$

Australia's policy towards Timor-Leste provides a cogent case study of the problems of setting morality and expediency against each other. Consistently, politicians and officials insisted that relations with Indonesia were more important than what happened in East Timor and that their critics were naïve and idealistic. One thing that pragmatic arguments cannot survive is empirical failure. Decades after the 1975 invasion, Australian-Indonesian relations are cool and distrustful. Despite frequent disappointments and the trauma of its tragic history, Timor-Leste continues to seek friendship with Australia. This is testament to economic interest, but also to recognition of the chasm between Australian public opinion on Timor-Leste and the cynical pragmatism of Canberra. Meanwhile, relations between Timor-Leste and Indonesia are now much better than either country's relationship with Australia. According to former President Xanana Gusmão, 'Our countries enjoy a close friendship and have become a global model for reconciliation.' 19

As pragmatism continues to trump principle, the trilateral relationship produces some acute ironies. Thus, for example, after fears of communist infiltration had caused such impact on East Timor's and Indonesia's history, Australia's treatment of Timor encouraged Chinese companies to engage in

17 C Fernandes, Reluctant Saviour: Australia, Indonesia and the Independence of East Timor (Scribe Publications, 2004).

18 Ibid.

19 Quotation reproduced from Maritime Boundary Office (мво), Timor-Leste's Maritime Boundaries (Government of Timor-Leste, 2016) 3. A hero of the resistance, Xanana Gusmão went on to be President (2002-2007), Prime Minister (2007-2015), Minister of Planning and Strategic Investment, lead negotiator with Australia over maritime boundaries, and a continuing force in Timor-Leste's governance. 
Timor Sea exploration as well as other commercial development. ${ }^{20}$ China is also a major purchaser of gas from the Timor Sea and seems likely to gain a hold over Timor-Leste through investment in infrastructure. ${ }^{21}$ Meanwhile, fears in the mid-197os about Timor-Leste becoming the 'Cuba of South Seas'22 now look quaint as Cuban support for East Timor is 'winning the hearts and minds of the people' by 'delivering basic health care and literacy to the rural poor.'23 Thanks to Cuba's training program, Timor-Leste has 'more doctors per capita than any other country in south-east Asia. ${ }^{24}$ With walls in Dili carrying anti-Australian slogans, 'it is the Chinese and the Cubans who are making the greatest advances - politically, economically and socially - in shaping its future. 25

This is a harsh story of realpolitik, in which fears about destabilization in the region and concern to develop political and economic links with Indonesia took precedence over responsible friendship, integrity, human rights and national sovereignty. As an Australian parliamentary committee reported, 'Australian policy towards East Timor has often been characterized as one in which pragmatism, expediency and self-interest have prevailed at the expense of a more principled approach. ${ }^{26}$ Decolonization and neo-colonialism are seen very differently if one sits in Dili rather than Canberra - or London or Washington - for the United Kingdom and the United States were also directly implicated in the suffering of the East Timorese in the final quarter of the last century.

20 RJ King, 'A Gap in the Relationship: The Timor Gap 1972-2013', Submission No 13 to the inquiry by the Australian Parliament Joint Standing Committee on Foreign Affairs, Defence and Trade into Australia's Relationship with Timor-Leste (27 March 2013) 74.

21 On the potential for Chinese investment in Timor-Leste's oil industry, see D Evans, 'Overblown Expectations for East Timor's Greater Sunrise Oil and Gas' Forbes (2 March 2018) and section 12, below.

22 W Way (ed.), Australia and the Indonesian Incorporation of Portuguese Timor, 1974-1976 (Melbourne University Press, 200o) 419; see also R Woolcott, The Hot Seat (HarperCollins, 2003) 145 .

23 P Quiddington, 'East Timor's Big, Dopey Neighbour Really Needs to Wake Up' Sydney Morning Herald (11 September 2009).

24 K Hodal, 'Cuban Infusion Remains the Lifeblood of Timor-Leste's Health Service' The Guardian (25 June 2012).

25 Quiddington, above (n 23); see also 'Cubans Bring Democracy, One Letter at a Time' Sydney Morning Herald (5 September 2009); T Anderson, 'Solidarity Aid: the Cuba-TimorLeste Health Program' (2008) 1 International Journal of Cuban Studies 53-65.

26 Senate Committee, East Timor: Final Report of the Senate Foreign Affairs, Defence and Trade References Committee (Commonwealth of Australia, 2000) 73. 
Australia's economic interest in Timor's resources has a long history. Indeed, 'the first oil concession sought by an Australian business dates from 1905.27 Significant exploration began in the early 196os when the Australian Government granted permits to operate in the Timor Sea to what has since become Woodside Energy (Australia's largest independent oil and gas company). In so doing, Australia asserted its claim to the seabed to the edge of a continental shelf running up to the Timor Trough (although this is only some $70 \mathrm{~km}$ from Timor), arguing that this accorded with Australia's sovereign rights under Article 1 of the 1958 Convention on the Continental Shelf. ${ }^{28}$

In the 1970s, references to maritime boundaries and oil extraction appeared with increasing frequency and focus in Australian government records. ${ }^{29}$ From this period 'the desire to control oil and gas in the Timor Sea influenced (the Department of Foreign Affairs) thinking in favour of East Timor's integration with Indonesia., ${ }^{30}$ Commercial investment and resource development required stability and certainty about maritime boundaries and resource extraction rights, so legal and political clarification became increasingly attractive. Borders are constructed purposively, which often includes serving economic needs. The corollary is that a frontier space where there is no clear legal delimitation of authority and sovereignty may be socially, politically, and economically undesirable.

As early as 1965, a cabinet document showed that the Australian Government saw 'no practicable alternative' to eventual Indonesian takeover of East Timor. ${ }^{31}$ Australia rebuffed requests from Portugal in 1970 for negotiations over a maritime boundary, preferring to make a deal first with Indonesia. ${ }^{32}$ In 1972, Australia and Indonesia agreed to a treaty which set a maritime boundary between those countries based on the continental shelf delineation. ${ }^{33}$

27 J Cotton (ed.), East Timor and Australia (Australian Defence Studies Centre, 1990) 1.

28499 UnTs 311.

29 Way, above (n 22). However, this collection excluded some crucial documents on Australia's Timor Sea oil and gas interests: K McGrath, Crossing the Line: Australia's Secret History in the Timor Sea (Redback, 2017) 7-9.

$30 \quad$ P Cleary, Shakedown: Australia's Grab for Timor's Oil (Allen \& Unwin, 2007) 16.

31 King, above (n 20), 9.

32 Conciliation between the Government of the Democratic Republic of Timor-Leste and the Government of the Commonwealth of Australia, Opening Session, 29 August 2016, PCA Case No 2016-10, 23; see also, Way, above (n 22), 111-112.

33 Agreement between the Government of the Commonwealth of Australia and the Government of the Republic of Indonesia establishing Certain Seabed Boundaries in the 
According with an approach which was accepted in international law (but about to be challenged), ${ }^{34}$ this greatly favoured Australia, as the configuration of the natural continental shelf put the maritime boundary much closer to Indonesian West Timor. ${ }^{35}$ Indonesia's willingness to be so accommodating to Australia has been ascribed to President Soeharto's interest in good relations, and the accompanying economic aid and political support. ${ }^{36}$ The legal technicality of borders and boundaries must be viewed in the political and economic contexts in which they are negotiated. Soeharto was seen as a man with whom the Australian Government could do business, despite his regime's corruption, authoritarianism and slaughter of so many of its own people in the anti-communist purge of $1965-66 .{ }^{37}$ The 'expectation that President Soeharto would be as accommodating in negotiating a seabed treaty in the Timor Sea to the south of East Timor'38 would be disappointed, but not before contributing to Indonesian confidence that a brutal invasion of East Timor would be tolerated by Australia.

Borders and boundaries are conventionally envisaged as dividing one State from another. However, in many instances, other states' interests may be directly involved. The failure to include Portugal in maritime boundary negotiations created the problem of the 'Timor Gap' - the sea off East Timor's south coast. It was in Australia's and Indonesia's common interest to define the Timor Gap as narrowly as possible, despite the impact on a third State - or indeed, in order to marginalise that State's interest. Richard Woolcott, subsequently Australian Ambassador to Indonesia, gave the facile realpolitik justification that it was simpler and more practical to complete the complex seabed boundary negotiations with Indonesia than it would have been with Portugal or an independent East Timor'.39

Only when a treaty had been signed with Indonesia did Australia offer to negotiate with Portugal. Portugal replied that negotiations should be delayed

Area of the Timor and Arafura Seas, Supplementary to the Agreement of 18 May 1971 (1972 Treaty), [1973] ATs 32.

34 M Evans, 'Maritime Boundary Delimitation' in D Rothwell, A Oude Elferink, K Scott and T Stephens (eds), The Oxford Handbook of the Law of the Sea (Oxford University Press, 2015) 254-279.

35 RJ King, 'The Timor Gap, Wonosobo and the Fate of Portuguese Timor' (2002) 88 Journal of the Royal Australian Historical Society 75-103, 83-4.

$36 \quad$ King, above (n 20).

37 The 'despite' in this sentence may well be inappropriate. Robinson (above $\mathrm{n}$ 11) makes clear that the United States and the United Kingdom were implicated in the purge.

38 King, above (n 35), 75 .

39 Woolcott, above (n 22), 156; see also Way, above (n 22), 52 . 
until the determination of the Third United Nations Conference on the Law of the Sea (which began in 1973), expecting it to confirm the shift in international law towards defining boundaries primarily by medians rather than geophysical features such as continental shelves. ${ }^{40}$ However, Portugal did not hold off granting exploration permits in 1974 to an American company in part of the Timor Sea claimed by Australia, much to Canberra's displeasure. ${ }^{41}$ The significance of all this increased when, in 1974, Woodside discovered the massive hydrocarbon potential of the Greater Sunrise Field. Coinciding with the declining production outputs from Australia's major oil fields elsewhere, this attracted great interest from Australian officials and companies. ${ }^{42}$

\section{$4 \quad$ 'Now Where's the Champagne?'3}

As noted above, the Australian Government had good reason to think that Indonesia would be easier to deal with than either Portugal or an independent East Timor. Clearly, it is an overstatement to claim that Australian governmental complicity in Indonesia's destabilization and invasion of East Timor was simply 'rooted in the desire for oil'. ${ }^{44}$ Political factors (fears of communism, concerns about regional stability, prioritization of relations with Indonesia) were also significant. However, there can be no doubt that consideration of East Timor's future was contaminated by Australian economic self-interest. As an Australian senator put it in 1973, the reserves in the Timor Sea promised to match 'the fabulous riches of the Middle East'. 45

The 1975 invasion opened the way for Australian-Indonesian negotiations to close the Timor Gap, which Australia expected to be straightforward, hoping 'to simply rule a line to join the end points of the existing seabed boundaries with Indonesia. ${ }^{46}$ This optimism was a significant factor in Prime Minister Whitlam's notoriously ambivalent signals to Soeharto about incorporation

\footnotetext{
$40 \quad$ King, above (n 20), 9-12.

41 GJ Aditjondro, Is Oil Thicker than Blood? A Study of Oil Companies' Interests and Western Complicity in Indonesia's Annexation of East Timor (Nova Science Publishers, 1999) 12-13; see also, King, above (n 35), 86-7; King, above (n 20), 12-13; Way, above (n 22), 111.

42 A Bergin, 'The Australian-Indonesian Timor Gap Maritime Boundary Agreement' (1990) 5 International Journal of Estuarine and Coastal Law 383-93, 384.

43 Foreign Minister Gareth Evans, celebrating the Timor Gap Treaty, quoted in 'Drawing the Line' ABC Four Corners (17 March 2014).

44 Cleary, above (n 30), 32.

45 J O'Byrne, quoted in King, above (n 35), 85.

46 мво, above (n 19), 17.
} 
and self-determination. ${ }^{47}$ When Whitlam's successor, Malcolm Fraser, visited Jakarta in 1976, he was accompanied by the managing director of внР, which had a controlling interest in (what was then) Woodside-Burma. ${ }^{48}$ However, this time the Indonesian Government would not be so accommodating: realizing what a poor deal the 1972 Treaty had been, they argued for a median line boundary according with emerging international law. ${ }^{49}$

It seemed that the Australia Government's acquiescence to Indonesia's invasion of East Timor had come to nothing. However, obstacles to offshore resource exploitation resulting from the failure to agree on a legal boundary were eventually overcome by negotiating a resource sharing agreement. In 1989, Australian and Indonesian politicians signed the Timor Gap Treaty, providing for development of the seabed in the area off Timor which had not been covered by the 1972 Treaty. Proceeds were to be equally shared between Australia and Indonesia. ${ }^{50}$ This took place during a champagne-accompanied ceremony on a flight over the Timor Sea. As one academic commentator has observed, Indonesian Foreign Minister Ali Alatas being toasted by his Australian counterpart, Gareth Evans, 'represented the photo-snap image of Australia's recent history of moral and political bankruptcy in relation to East Timor. ${ }^{51}$ Australia caused great offence in East Timor by signing this treaty. Xanana Gusmão denounced it as 'a total betrayal by Australia of the Timorese people.52 The reason deserves emphasis: Australia was agreeing to benefit from one of the worst crimes of the twentieth century. Australia was the first country to recognise Indonesian sovereignty over East Timor. Doing so was a necessary precursor to entering into legal agreements about boundaries and resource-sharing, despite the recognition being arguably in breach of international law. ${ }^{53}$ Before the International Court of Justice, Portugal attempted to challenge this agreement to exploit an area for which it was still (according to

$47 \quad$ King, above (n 35), 93 .

48 Nevins, above (n 4), 9; see also, J Pilger, Distant Voices (Vintage, 1994) 257-258.

491982 United Nations Convention on the Law of the Sea (LOSC), 1833 UnTS 3.

50 Bergin, above (n 42); Senate Committee, above (n 26), ch 4; 1989 Timor Gap Treaty, [1991] ATS 9.

51 Balint, above ( $\mathrm{n}$ 5), 45. See also S Maloney and C Grosz, 'Gareth Evans and Ali Alatas' The Monthly (December 2011). Airily dismissing his hypocrisy on the ground that the signing seemed a good idea at the time (G Evans, Incorrigible Optimist (Melbourne University Press, 2017) 148), Evans has the hide to publish articles with titles such as 'Crimes against Humanity: Overcoming Indifference' (2006) 8 Journal of Genocide Research 325-339.

$5^{2}$ Letter to Prime Minister Hawke, quoted in King, above (n 20 ), 28.

53 RS Clark, 'Some International Law Aspects of the East Timor Affair' (1992) 5 Leiden Journal of International Law 265-271; RS Clark, 'Timor Gap' in P Carey and GC Bentley (eds), East Timor at the Crossroads (University of Hawaii, 1995) 73-94. 
United Nations resolutions) responsible, but this was blocked by Indonesia's refusal to accept the Court's jurisdiction. ${ }^{54}$

\section{$5 \quad$ Chega $^{55}$}

This attempt to resolve the Timor Gap problem threatened to unravel when Timor-Leste emerged as an independent State following Indonesia's withdrawal in 1999. Australia's political leaders had assisted belatedly and reluctantly, but its troops led the International Force East Timor (INTERFET) mission bravely and effectively. ${ }^{56}$ What had been an internal division between two Indonesian provinces became an international border once again. While its precise delineation would be a lengthy process, this was less complicated than the tasks of drawing maritime boundaries and negotiating associated resource sharing agreements.

Australia sought to minimise the economic impact of independence by replicating the resource sharing arrangements made with Indonesia. Former President José Ramos-Horta put it bluntly: 'Ever since our independence, Australia has tried to push down our throats the same arrangement it unfairly managed to sell to Indonesia. ${ }^{57}$ Australia was keen to continue the existing arrangement out of concern that Indonesia would seek to renegotiate the 1972 Treaty if it saw Timor-Leste getting a better deal: Australia had benefited significantly from exploiting resources in an area which a treaty drawing a median line would have allocated entirely to Indonesia. ${ }^{58}$ In fact, Australia did not wait for TimorLeste's formal independence and had sought to prepare the ground by negotiating a Memorandum of Understanding with the United Nations Transitional Administration in East Timor (UNTAET), providing for post-independence application of the Timor Gap Treaty's provisions to Australia's continuing development in the Timor Sea of a 'Joint Petroleum Development Area' (JPDA).59

54 Case Concerning East Timor (Portugalv Australia), (1995) ICJ Reports, p 90.

55 Portuguese for 'no more, stop, enough'. See CAVR, above (n 10).

56 Fernandes, above ( $\mathrm{n} 17)$.

57 J Ramos-Horta, Timor-Leste and Southeast Asia, the State of Democracy and Human Rights, Keynote speech, Fifth Southeast Asian Studies Symposium, 14 April 2016, Oxford, 6. See also J Ramos-Horta, Words of Hope in Troubled Times (Longueville, 2017). Nobel Peace Laureate Ramos-Horta was Timor-Leste's President, then Prime Minister, 2006-2012, and co-founder of the Diplomacy Training Program.

$5^{8}$ Senate Committee, above (n 26), 6o, 73 .

59 Memorandum of Understanding on Arrangements Relating to the Timor Gap Treaty, adopted 10 February 200o, http://www.atns.net.au/agreement.asp?EntityID=2440; accessed 1 July 2018. 
On 20 May 2002, the day of independence, Timor-Leste signed the Timor Sea Treaty (TST) with Australia to govern the exploitation of oil and gas resources in the JPDA. ${ }^{60}$ The TST split the benefits of the JPDA 90-10 percent in TimorLeste's favour, sailing 'as close to recognition of East Timor's sovereignty over the disputed seabed as it is possible to manoeuvre without conceding the point entirely'. ${ }^{61}$ As Strating points out, ' $\mathrm{t}$ ] he quid pro quo for the unequal split was Australia winning lucrative downstream revenues via rights to pipe gas from the JPDA to Darwin'.62 Subsequent attempts to negotiate the boundary failed, so the TST was followed by the 2006 Treaty on Certain Maritime Arrangements in the Timor Sea (CMATS).${ }^{63}$ Instead of a boundary, the outcome was an agreement to share benefits equally from areas outside the JPDA, including Greater Sunrise.

Timor-Leste was under pressure from oil companies and international donors to make an agreement allowing oil and gas to flow. ${ }^{64}$ While allocating Timor-Leste half the non-JPDA revenues, CMATS put 'a moratorium on "asserting, pursuing or furthering" a permanent maritime boundary for the next 50 years' ${ }^{65}$ The Australian Government hoped that there would be no talk of maritime boundaries until Greater Sunrise had been exhausted, by which time the location of the boundary would be economically inconsequential. However, CMATS also provided for its own termination by either State if a development plan for Greater Sunrise had not been approved within six years. The Australian Government claimed that the allocations of shares of JPDA and CMATS revenues were acts of pure generosity to Timor-Leste: former Foreign Minister Downer spoke of personally giving these benefits to the Timorese for whom he had 'a soft spot'.66 Downer even claimed, 'We gave East Timor its freedom and its independence. ${ }^{67}$ Such patronizing attitudes and historical insensitivity rankled in Timor-Leste, increasing resentment and encouraging

\footnotetext{
6o [2003] ATS 13 .

61 G Triggs and D Bialek, 'The New Timor Sea Treaty and Interim Arrangements for Joint Development of Petroleum Resources of the Timor Gap' (2002) 3 Melbourne Journal of International Law 322-363, 333.

62 R Strating, 'Timor-Leste's Foreign Policy Approach to the Timor Sea Disputes' (2017) 71 Australian Journal of International Affairs 259-283, 262.

63 [2007] ATS 12. See Schofield, above (n 5).

64 Nevins, above (n 4), 7 .

65 мво, above (n 19), 20.

66 Quoted, 'Drawing the Line', above (n 43).

67 Quoted in Strating, above (n 62), 266.
} 
ambition. ${ }^{68}$ Australia could not give away something that it had never properly owned: the ownership of the seabed was the essence of the dispute.

\section{$6 \quad$ Negotiating a Solution}

Proposing that matters decided in the difficult circumstances following independence should be renegotiated, Gusmão stated: 'the achievement of maritime boundaries in accordance with international law is a matter of national sovereignty and the sustainability of our country. It is Timor-Leste's top national priority' ${ }^{\prime} 9$ This raised domestic expectations and reduced the room for compromise in the subsequent negotiation process.

The Australian Government rebuffed Timor-Leste's initial attempts to open negotiations about a maritime boundary, so a way was found to make engagement unavoidable. Timor-Leste launched proceedings in the Permanent Court of Arbitration (PCA) in 2013 seeking to invalidate CMATS on the ground that it had not been negotiated in good faith because of Australia's espionage (see section 10 below), and requesting compulsory mediation under the 1982 United Nations Convention on the Law of the Sea (LOSC). ${ }^{70}$ While Australia modified its acceptance of the compulsory jurisdiction of the International Court of Justice in disputes concerning maritime delimitation, this attempt to avoid legal responsibility was not fully effective. Timor-Leste was still able to activate the compulsory conciliation procedure under Article 298 and Annex V of the LOSC. A Conciliation Commission began work in mid-2016, with the PCA acting as a registry for the proceedings. Australia tried to block the Commission's work and, when this failed, 'repeatedly emphasised the non-binding nature of the UNCC recommendations. ${ }^{71}$ Nonetheless, for reasons to be discussed below, Australia thereafter engaged positively and this innovative activation of conciliation under the LosC led to significant results.

In January 2017, Timor-Leste activated its option to terminate CMATS, removing that treaty's block on negotiating maritime boundaries. It also dropped

68 J Texeira, Minister with Responsibility for Natural Resources, 2002-2007, in 'Rich Man, Poor Man' ABC Four Corners (1o May 2004) 7, http://www.abc.net.au/4corners/content/ 2004/s1105310.htm; accessed 1 July 2018).

69 Conciliation Proceedings between the Government of the Democratic Republic of TimorLeste and the Government of the Commonwealth of Australia, Opening Session, 29 August 2016, PCA Case No 2016-10, 21.

70 мво, above (n 19), 16.

71 B Strating, 'Timor-Leste Runs the Risk of a Pyrrhic Victory' The Interpreter (11 January 2017). 
its legal actions against Australia, allowing the latter to negotiate without the embarrassment of public criticism spurred by proceedings about spying and bullying (see below). In a significant change of policy, Australia agreed to negotiate on boundaries, joining with Timor-Leste and the Conciliation Commission in making a 'commitment to work in good faith towards an agreement on maritime boundaries. ${ }^{72}$

The 2018 Treaty, which emerged from the Commission's work, was announced with great optimism. According to the Conciliation Commission's Chair, the kangaroo of Australia and the crocodile of Timor-Leste were dancing together. ${ }^{73}$ In light of the history outlined above, the unlikeliness of this rapprochement calls for some explanation. Australia's new enthusiasm for international legality must be set against its need to distinguish itself from China. Its attempt to disengage from cMATs had left the Australian Government open to accusations of hypocrisy when, in the context of the South China Sea dispute, its Foreign Minister lectured the Chinese Government on the importance of international law, referring to the LOSC as 'the foundation for peace stability and prosperity in East Asia. ${ }^{74}$ Displaying considerable chutzpah, a Department of Foreign Affairs and Trade (DFAT) official claimed that Australia's dealings with Indonesia and Timor-Leste 'show Australia's commitment to rules-based order. ${ }^{75}$ The Dili-based NGo La'o Hamutuk acidly enquired: 'Do some of the "Rule of Law" trainers and advisors AusAID pays to work in Dili need to build capacity in Canberra?'76

Concern over China's outreach in the South China Sea dwarfed that over Australia and Timor-Leste's disagreements. Australia came under diplomatic pressure from its allies to deal with the embarrassment of its apparently

72 Conciliation Proceedings between the Government of the Democratic Republic of TimorLeste and the Government of the Commonwealth of Australia, Joint Statement by the Governments of Timor-Leste and Australia and the Conciliation Commission constituted pursuant to Annex V of UnCLOS, 9 January 2017, PCA Case No 201-10. The Conciliation Commission produced a full account of its process in Report and Recommendations of the Compulsory Conciliation Commission between Timor-Leste and Australia on the Timor Sea, 9 May 2018, PCA Case No 2016-10.

73 'Remarks delivered by HE Ambassador Peter Taks $\varphi$ e-Jensen on the occasion of the signature of the Timor-Leste Maritime Boundaries Treaty', https://pcacases.com/web/sendAttach/2303; accessed 1 July 2018.

74 T Clarke, 'Australia as Guilty as China' Sydney Morning Herald (15 July 2016) 17.

75 A Cox, 'Timor Sea Treaties show Australia's Commitment to Rules-based Order' The Interpreter (4 March 2016).

76 '2012-2016: Protesting the Australia-Timor-Leste cmats Treaty to Compel Boundary Negotiations: Events in 2013' La'o Hamutuk (2020), http://www.laohamutuk.org/Oil/ Boundary/CMATSindex.htm; accessed 30 September 2020. 
unprincipled ambivalence towards the Losc. ${ }^{77}$ In 2017, the US House of Representatives Armed Services Committee reported that boundary negotiation between Australia and Timor-Leste 'sends a positive signal to other states in the region regarding adherence to a rules-based international order ... and could serve as an example for resolving disputes peacefully and could have benefits to cooperative maritime efforts in the region', directing the Secretary of Defense to report on 'how a peaceful resolution might affect overall US defense and security interest in the region. ${ }^{78}$ The message to Canberra was clear: deal with this. So, Australia brazenly shifted the Timor issue from embarrassment to exemplar. Australia's 2017 Foreign Policy White Paper introduced the agreement with Timor-Leste as 'a testament to the way international law, in particular the UNCLOS, reinforces stability and allows countries to resolve disputes peacefully ... It is an example of rules-based order in action' ${ }^{79}$ The White Paper was too busy making veiled critical references to China and to the South China Sea as 'a major fault line in the regional order' and to its commitment to building 'a region where disputes are solved ... in accordance with international law' to acknowledge the hypocrisy of its position on the Timor Sea. ${ }^{80}$ By late 2017 , the Secretary of DFAT was bluntly linking the issues, asserting that China would do well to follow Australia's law-abiding example. ${ }^{81}$ This hypocritical bluster is likely to be more appealing in Canberra and Washington than in Beijing, where memories tend to be longer.

\section{Resources and Boundaries in the Timor Sea}

The first map shows the borders of various kinds in the Timor Sea between 2002 and the 2018 Treaty (Figure.2.1). The JPDA included Bayu-Undan, the largest of several fields which are reaching the end of their life. ${ }^{82}$ Output is piped to a processing facility in Darwin, Australia.

\footnotetext{
77 M Leach, 'Bridging the Timor Gap' Inside Story (4 September 2017).

78 United States Congress, Report of the Committee on Armed Services, House of Representatives, on HR 2810, Together with Additional Views, Report \#115-200, https://www. gpo.gov/fdsys/pkg/CRPT-115hrpt20o/pdf/CRPT-115hrpt2oo.pdf; accessed 1 July 2018.

79 Australian Government, Foreign Policy White Paper (Australian Government, 2017) 105.

8o $\quad$ Ibid 46 .

81 F Adamson, 'International Law and Australia's National Interests', speech to the Australian Strategic Policy Institute (4 October 2017), http://dfat.gov.au/news/speeches/Pages/ international-law-and-australias-national-interests.aspx; accessed 1 July 2018.

82 Government of Timor-Leste, Timor Leste Strategic Development Plan 2011-2030 (2011), 136140, 205, http://timor-leste.gov.tl/?p=5289\&lang=en; accessed 1 July 2018.
} 


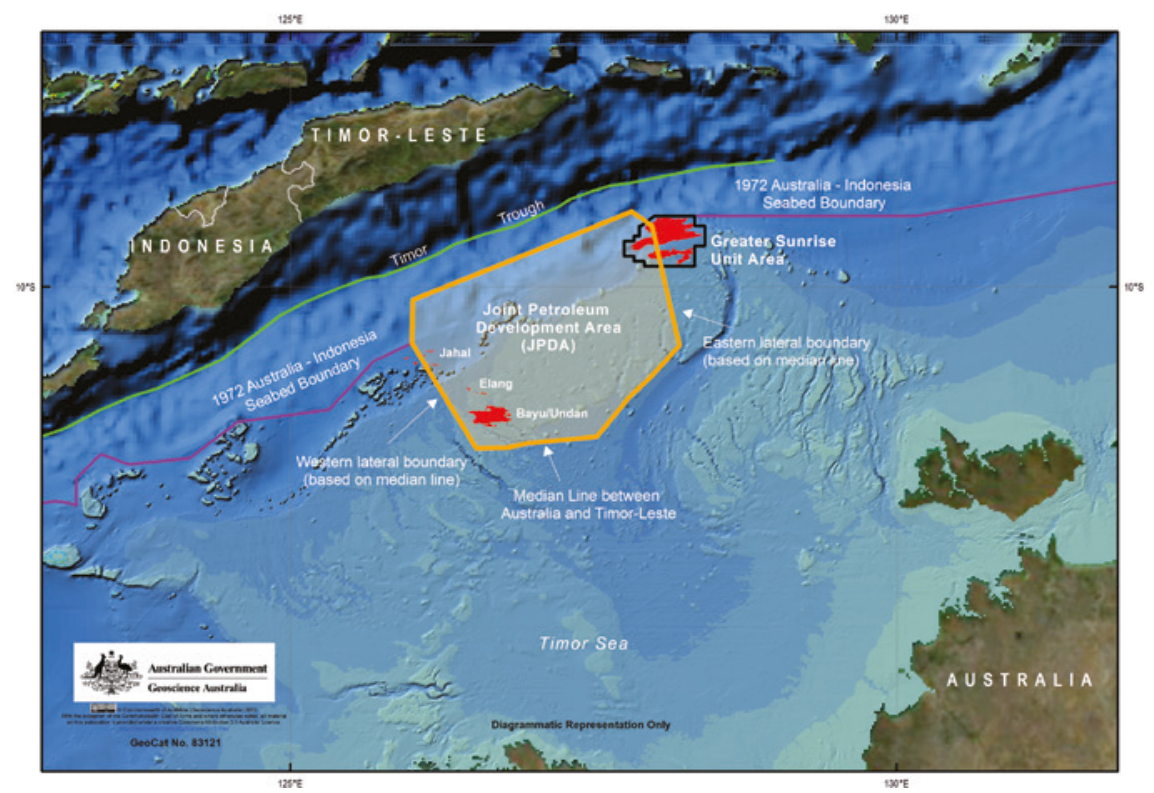

FIGURE 2.1 The Timor Sea, 2002-2018. Geoscience Australia, Australian Government

The JPDA was located amidst a series of maritime areas. Immediately to the north were Timor-Leste's coastal waters. On either side to the northeast and to the northwest, areas of coastal waters were held by Indonesia under the 1972 Australia-Indonesia Treaty. To the south, there was the area stretching from the median line to Australia: Timor-Leste made no claim to this. To the west, there was an area including a series of major fields - Laminaria, Corallina, Buffalo which lay north of the median but outside the JPDA. These have been 'fully or mostly depleted by Australia' which has taken all the proceeds, ignoring valid arguments that the funds from such fields should go into an escrow account until boundary negotiations were complete. ${ }^{83}$ While Australia continues to provide aid to Timor-Leste, its value is calculated to be half that which Australia has received from the Laminaria-Corallina field alone. ${ }^{84}$ Finally, straddling the eastern edge of the JPDA, there is Greater Sunrise (Sunrise and Troubador) which has 'the largest known deposits of hydrocarbons in the Timor Sea' ${ }^{85}$ It is this border - the eastern lateral - which was at the heart of the dispute leading to (and beyond) the 2018 Treaty. Because only 20 percent of Greater

83 Triggs and Bialek, above (n 61); мво, above (n 19), 11.

84 Timor Sea Forum, Time for Fair Borders in the Timor Sea (TimorSeaJustice, 2015).

85 мво, above (n 19), 56 . 
Sunrise lay within the JPDA, an agreement between Australia and Timor-Leste in 2003 provided for its unitization. ${ }^{86}$ CMATs allocated 50 percent of the nonJPDA area proceeds to Timor-Leste, while (as noted above) it got go percent of the JPDA proceeds.

\section{$8 \quad$ A Median Line?}

Timor-Leste's argument for a median line could rightly claim to be consistent with several decades of boundary determination law and practice. ${ }^{87}$ Publicity for Timor-Leste's case focused on the median line, as it lent itself to a straightforward argument for fairness. Its persuasiveness is illustrated by an Australian Joint Select Committee on Treaties (JSCT) report on CMATs, which noted that: 'A large number of submissions support the position of Timor-Leste in the maritime boundary dispute - a delineation of boundaries based on the median line principles - and argue that the cmats Treaty denied Timor-Leste of oil and gas reserves that should fall within its sovereign maritime boundaries'. ${ }^{88}$ This characterization of the matter must have encouraged Timor-Leste. Drawing a median line is more complicated than simply finding a mid-way point. If a proportionality test taking into account the different lengths of the two coastlines, as in the dispute between Malta and Libya, had been applied, the median could have been set well above half-way between Australia and Timor, leaving East Timor without a claim to fields such as Bayu-Undan. ${ }^{89}$ However, the 2018 Treaty provided Timor-Leste with the straightforward median line running from east to west for which it had argued so strongly. While this was a symbolic and political victory, its economic significance was limited because it did not in itself give Timor-Leste control of Greater Sunrise. For this, Timor-Leste had to run a much harder argument - the redrawing of the lateral boundaries running north to south.

862003 Agreement between the Government of Australia and the Government of the Democratic Republic of Timor-Leste relating to the Unitization of the Sunrise and Troubadour Fields, adopted 6 March 2003, in force 23 February 2007, [2007] ATS 11.

87 Evans, above (n 34); Schofield, above ( $n_{5}$ ), 198.

88 Parliament of Australia, Joint Select Committee on Treaties (JSCT), Certain Maritime Arrangements - Timor-Leste, Report 168 (JsCT, 2017), 2.20.

89 Triggs and Bialek, above (n 61), 362; F Brennan, The Timor Sea's Oil and Gas: What's Fair? (Australia Catholic Social Justice Council, 2004) 31; D Ong, 'The New Timor Sea Arrangement 2001' (2002) 17 International Journal of Marine and Coastal Law 79-122, 87-89. 


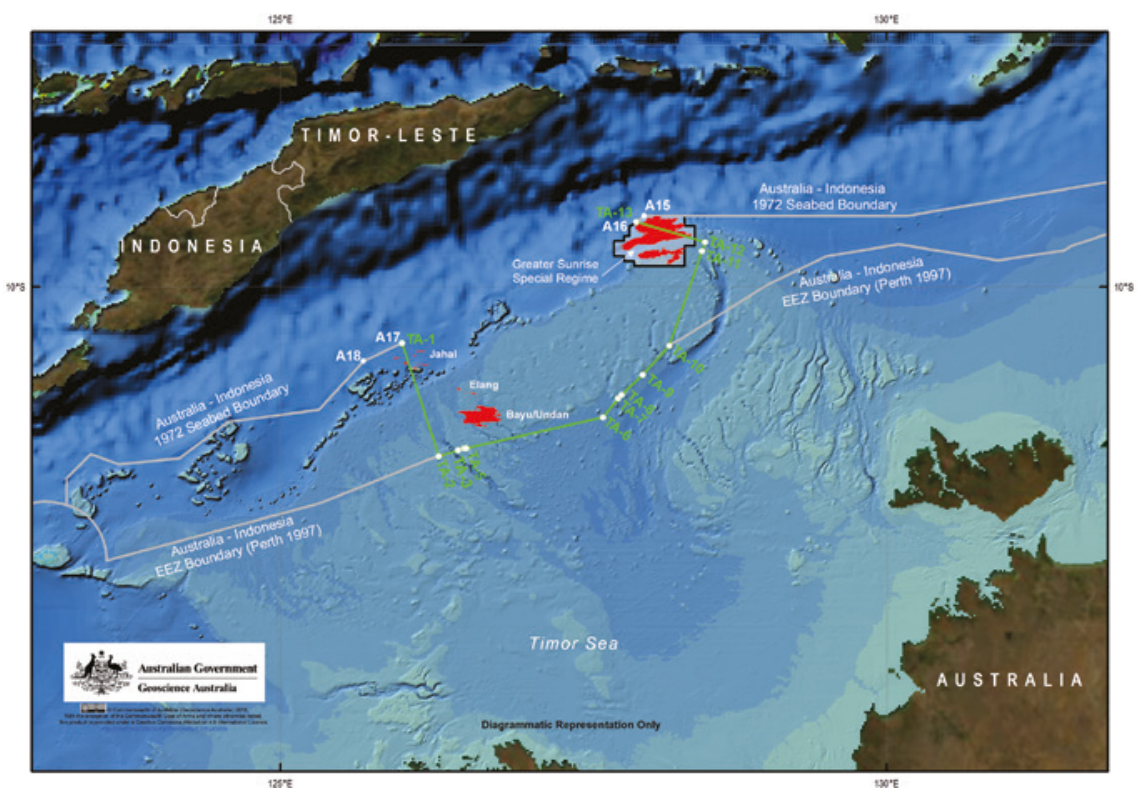

FIGURE 2.2 The 2018 Timor Sea Treaty. Geoscience Australia, Australian Government

To the West of the JPDA, Timor-Leste relied on Lowe, Carleton and Ward's legal opinion to argue for a boundary set by calculating a perpendicular from the coast. ${ }^{90}$ Despite some doubts about the justification for this, ${ }^{91}$ Australia agreed to re-drawing the western lateral by allocating a triangle west of the JPDA to Timor-Leste. However, this was subject to one crucial condition: the 2018 Treaty debarred Timor-Leste from any claim to a retrospective share of the historical proceeds from Corallina, Laminaria and Buffalo (Figure.2.2).

Even more contentious was the area including much of Greater Sunrise to the east of the JPDA. A change which did no more than set the median line as the maritime boundary would be of limited benefit to Timor-Leste. While potentially increasing its share from 90 to 100 percent of the proceeds from the fifth of Greater Sunrise within the JPDA, this would leave out the complex issue of the remaining bulk to the east, an area allocated to Australia by the Australia-Indonesia 1972 Treaty. As noted, Timor-Leste obtained 50 percent

\footnotetext{
90 VLowe, C Carleton and C Ward, 'In the Matter of East Timor's Maritime Boundaries' Legal Opinion (22 April 2002) 15, https://www.laohamutuk.org/OilWeb/Company/PetroTim/ LegalOp.htm; accessed 1 July 2018.

Triggs and Bialek, above (n 61), 351.
} 
of the proceeds under CMATs. Timor-Leste argued the boundary of the JPDA should be expanded further east because the Timor Gap had been too tightly drawn in the agreement between Australia and Indonesia that had excluded Portugal. Timor-Leste's case was that the 1972 eastern boundary did not take account of the island of Jaco, while giving too much effect to small Indonesian islands and coastal features which had been interpreted as requiring the Gap to converge from 140 nautical miles on the coast to 120 at the median line. Timor-Leste submitted that an appropriate maritime boundary would create an area which broadened out (rather than narrowed) from the coast to a simple median line so that Greater Sunshine sat comfortably within it. ${ }^{92}$

Despite insistent advocacy by Timor-Leste and its supporters, international law does not provide a simple method of setting lateral boundaries. Article 83(1) of the LOSC requires countries to delimit maritime boundaries by agreement 'in order to achieve an equitable solution', but does not mandate a particular methodology. This might have indicated the need for tripartite negotiations involving Timor-Leste, Australia and Indonesia. It had been acknowledged in the 1970s 'that those endpoints might have to be revised were there ever to be any negotiations among all three parties with an interest in the Timor Sea. ${ }^{93}$ However, doing so might have encouraged Indonesia to seek to renegotiate the 1972 Treaty, arguing that it should be updated to reflect current norms of maritime boundary settlement. ${ }^{94}$ Australia has been concerned that a wholesale review could be potentially 'a deeply unsettling development in our relationship with Indonesia and for our foreign policy generally'. ${ }^{95}$

Fortunately for Australia, Indonesia seems in no hurry to renegotiate the 1972 Treaty. Making no claim to Greater Sunrise, Indonesia treated the matter as settled in dealings with the UN Commission on the Limits of the Continental Shelf

92 мво, above (n 19), 8, 64, 68; Brennan, above (n 89), 28, 42, 48; V Prescott, 'East Timor's Potential Maritime Boundaries' in DR Rothwell and M Tsamenyi (eds), The Maritime Dimensions of Independent East Timor (Centre for Maritime Policy, 2000) 79-105, 104.

93 Brennan, above (n 89), 22; see also Triggs and Bialek, above (n 61), 342; King, above (n 35), 82. In late 2015, Timor-Leste and Indonesia began discussions to delimit maritime boundaries: see Gusmão, quoted in PCA, above (n 72), 16; C Schofield and B Strating 'Timor Gap: A Boundary, yet Disputes Linger' The Interpreter (7 March 2018) 3. These negotiations resumed in late 2018 and early 2019: see Maritime Boundary Office, Newsletter November 2018-March 2019, https://www.laohamutuk.org/Oil/Boundary/2019/MBONewsletterMar2o1gen.pdf; accessed 1 July 2018.

94 S Bateman and DR Rothwell, 'Rethinking Australia's Legal and Policy Options in the Timor Sea' in Rothwell and Tsamenyi (eds), above (n 92), 171-177, 174.

Alexander Downer, quoted in Triggs and Bialek above (n 61), 363 . 
in 2009. ${ }^{96}$ It appears that Indonesia's focus is on the maritime boundaries to the north rather than the south of Timor and that it regards itself as 'well-endowed with energy resources elsewhere and has yet to develop significant identified resources well within its sovereign boundaries, ${ }^{97}$ Indonesia may well not relish having to negotiate with Woodside and other companies which would have to be convinced of the commercial security of developing a field in Indonesian waters.

The complexity of national and commercial interests in the area surrounding Greater Sunrise meant that a simple eastern boundary - such as that claimed by Timor-Leste which would have put all of Greater Sunrise within its area - was an unlikely outcome. If Timor-Leste managed to negotiate borders which put Greater Sunrise in its exclusive zone, then 'Timor would be able to dismiss the joint venturers who were unwilling to contemplate (upstream processing) development in Timor and to enlist a developer sympathetic to Timor's nationalist development goals' ${ }^{98}$ China is an obvious possibility as an alternative partner. This made Australian retention of some of Greater Sunrise politically as well as economically important.

The 2018 Treaty produced what was effectively a resource sharing agreement dressed up as a boundary settlement. As Strating points out, 'the boundary is deceiving ... because Greater Sunrise remains subject to joint development' and is, in effect, 'a shared sovereignty zone until the field is depleted'. 99 A line was drawn north from the south-east tip of the JPDA. But rather than proceeding straight north-northeast to meet the boundary of Indonesian seabed, the line dog-legs north-west across Greater Sunrise, leaving a significant but anomalous enclave in Australia's jurisdiction (see Figure.2.2). Its function is confirmed by the unusual provision in the 2018 Treaty, which declares the arrangement to be temporary and to be subject to change when hydrocarbon extraction is complete and agreement has been reached between Indonesia and Timor-Leste delimiting the continental shelf boundary, when a simpler boundary will be completed. ${ }^{100}$ So Australia will only concede Timor-Leste's sovereign rights when they are economically worthless. The Treaty also establishes 'a special regime' for the development of the Greater Sunrise Field which

96 B Collaery, 'National Security, Legal Professional Privilege and the Bar Rules', address at the Australian National University, 11 June 2015, 24, https://law.anu.edu.au/sites/all/files/ events/national_security_legal_professional_privilege_and_the_bar_rules_print.pdf; accessed 1 July 2018.

97 Ibid 23; see also F Brennan, 'Timorese Have Had a Win but Could Still Lose Big-time' Eureka Street (16 January 2017).

98 Brennan, above (n 89).

99 R Strating, 'The Timor Sea Disputes' Australian Outlook (9 March 2018).

1002018 Treaty, above (n 1), Art 3. 
makes provision for management, dispute resolution and governance, establishes a process for producing a development plan and allocates at least 70 percent of the upstream revenue to Timor-Leste. ${ }^{101}$

The resource sharing arrangement is also conditional, depending on where the output from Greater Sunrise is processed. However, before exploring the processing issue, we will examine the emergence of the 2018 Treaty from the fractious relationship between Australia and Timor-Leste.

\section{$9 \quad$ Diplomacy, Conflicts and Interests}

Ata 2002 meeting in Timor-Leste, Australian Foreign Minister Alexander Downer was reported to have been 'belligerent and aggressive.' $102 \mathrm{He}$ 'thumped the table and abused' Prime Minister Alkatiri and his officials, ${ }^{103}$ telling them: 'We don't have to exploit the resources. They can stay there for $20,40,50$ years. We don't like brinkmanship. We are very tough ... Let me give you a tutorial in politics not a chance.'104 This incident says much about the Australian Government's condescending and self-interested treatment of its neighbour.

Just two months before Timor-Leste's independence in 2002, Australia modified its acceptance of the compulsory jurisdiction of the International Court of Justice so as to exclude maritime boundary disputes, preventing TimorLeste from seeking judicial determination of a boundary in the Timor Sea. ${ }^{105}$ While Australia was within its legal rights to do so, this was hardly the action of a country committed to the international rule of law. Downer explained that he did not want 'having courts and arbiters and, you know, people over there in The Hague deciding on our relationship' with neighbours. ${ }^{106}$ Following CMATs, Timor-Leste tried for several years to open negotiations about the maritime boundary or to renegotiate resource sharing, claiming that CMATS imposed unfair and disadvantageous arrangements on a country that, at its emergence to independence, was impoverished, disorganized, diplomatically and legally inexperienced, and dependent on foreign aid. ${ }^{107}$ Australia's representatives

\footnotetext{
101 Ibid Art 7 and Annex B.

102 N Wilson, 'Downer Accused of Abusing Timor PM' The Australian (13 December 2002).

103 King, above (n 20), $5^{2}$.

104 P Cleary, 'The 40-year Battle Over Timor's Oil' The Australian (5 December 2013).

105 A Sheehan, 'Dispute Settlement under UNCLOS: The Exclusion of Maritime Delimitation Disputes' (2005) 24 Universty of Queensland Law Journal 165-19o.

106 'Rich Man, Poor Man', above (n 68), 7.

107 мво, above (n 19), 19, 42; see also Gusmão in PCA, above (n 32), 17-18; Senate Committee, above (n 26), 569-571; King, above (n 20).
} 
reject this account, counter-claiming that 'Timor-Leste proposed many of the key aspects of these arrangements itself, celebrated them at the time as major achievements, and has benefited significantly from them'.108 The Australian Government claimed that Timor-Leste's 'change of heart in relation to the Timor Sea treaties has created uncertainty, raised sovereign risk, undermined investor confidence and considerably delayed Greater Sunrise's development.' ${ }^{109}$ From this perspective, Timor-Leste had done well from the exploitation of fields in the JPDA, which are or soon will be depleted, while facing the prospect of a less advantageous division of the spoils from Greater Sunrise. In addition, Timor-Leste is portrayed as petulantly reacting to Woodside's refusal (at this time) to pipe the output to a new processing facility in Timor-Leste which would boost the local economy (see discussion below).

The Timor Sea story has focussed attention on the close relations between the Australian Government and Woodside. A telling expression of this relationship has been the movement of people between them. In 2005, the retired head of DFAT, Ashton Calvert, was appointed to the Woodside Board. When Alexander Downer, Australia's long-serving foreign minister (1996-2007), left politics, he took a very lucrative consultancy with Woodside the following year. Soon after finishing as Energy and Resources Minister (2007-2013), Martin Ferguson went to work as an Australian Petroleum Production and Exploration Association lobbyist representing companies including Woodside, Shell, Exxon Mobil and B HP. Ferguson was replaced in Government by a former Woodside executive, Gary Gray, who was Resources and Energy Minister for several months in 2014. The closeness of relations between Woodside and the Australian Government justifies Collaery's description of Woodside as 'an instrument of foreign policy by proxy', ${ }^{\prime 10}$ although one could equally say that the Australian Government became an instrument of the commercial ambition of a corporate entity by proxy. Ostensibly, where interests coincide, there can be no conflict of interest. ${ }^{111}$

\footnotetext{
108 Justin Gleeson, Australian Solicitor-General, in PCA, above (n 32), 100.

109 Ibid 104.

110 Collaery, above (n 96), 35 .

111 See C Fernandes, Island Off the Coast of Asia: Instruments of Statecraft in Australian Foreign Policy (Monash University Publishing, 2019).
} 
Downer's consultancy with Woodside provoked an embarrassing and damaging revelation of how the Australian Government dealt both with Timor-Leste and with its own critics. During refurbishment of the Timor-Leste Government's offices in Dili in 2004, notionally as part of an AusAid development program, Australia took the opportunity to install listening devices which were used to spy on Timor-Leste's preparation for the CMATs negotiations. ${ }^{112}$ A worthy question which will probably never be answered is who, in the commercialgovernmental complex, first thought that bugging a friendly government for economic advantage was a good idea. Using aid work to camouflage espionage is highly irresponsible. As noted in one commentary, doing so 'runs the risk of endangering all legitimate aid workers who seek to help the disadvantaged ... To deploy intelligence agents under the cover of aid workers is to exploit the fragile trust that aid agencies must forge with their host country. It weakens their security because it discredits their altruism ... To excuse such actions as being in the national interest is breathtakingly cynical'.'13

Information about the bugging came from a former member of the Australian Secret Intelligence Service (ASIS), since identified as only as 'Witness K'. The background was resentment in sections of ASIS that the Dili operation had improperly diverted resources from investigation of a terrorist attack on Australia's embassy in Jakarta. ${ }^{114}$ Downer's appointment to Woodside was the final straw for Witness $\mathrm{K}$, who 'expressed disquiet at the diversion of scarce resources' and complained to the Inspector-General of Intelligence and Security. ${ }^{115}$ This provoked his dismissal. The Government claims that Witness K's action endangered Asis officers and their families, but the real threat was to development workers as a result of Asis espionage.

When, in 2013, Witness K attempted to travel to give evidence at The Hague in support of Timor-Leste's claim that the espionage meant that CMATS had been negotiated in bad faith, his passport was cancelled. ${ }^{116}$ The authorities then raided Witness K's home and the premises of Bernard Collaery, a

\footnotetext{
112 C Fernandes, 'Espionage against East Timor and the Need for Parliamentary Oversight' (2017) 42(1) Alternative Law Journal 71-73.

113 Editorial, 'Eroding the Propriety of the Timor deal' Sydney Morning Herald (11 December 2013).

114 Fernandes, above (n 112).

115 Ibid 72. Far from being a publicity-seeking whistle-blower, Witness $\mathrm{K}$ tried to use official channels of complaint.

116 Ibid.
} 
prominent Canberra lawyer who represents Timor-Leste's interests, seizing various documents and installing surveillance devices. ${ }^{117}$ Timor-Leste began action in the International Court of Justice seeking return of the documents. ${ }^{118}$ The Australian Government claimed that national security was at stake: it is rare that the economic interest of the country and the commercial interest of a major company have been so openly identified as matters of national security. ${ }^{119}$ In March 2014, the International Court of Justice made Australia the subject of an embarrassing interim order neither to use the material seized nor to obstruct contact between Timor-Leste and its lawyers. ${ }^{120}$ Australia returned the papers and the case was discontinued in 2015. ${ }^{121} \mathrm{~A}$ lasting effect of this affair was to allow Timor-Leste to take the moral high ground in arguing for new maritime boundaries, not least to deflect persistent claims about corruption and misconduct within its own government.

The Australian authorities might have been expected to be happy to see the bugging allegations slip from public notice. However, they just would not let it go. After an inordinate delay, Witness $\mathrm{K}$ and Collaery were charged in June 2018 with breaches of official secrets laws. Reports that Collaery planned to publish a book on the affair may have incited this. ${ }^{122}$ The Government may also have been sending a warning to other disaffected security service members and veterans. Those with any sense of irony may note that the then Australian Prime Minister was once the lawyer for the publishers in the Spycatcher proceedings ${ }^{123}$ and that the prosecution bears similarity to that of Clive Ponting over the release of the United Kingdoms's dirty secrets about the sinking of the General Belgrano during the Falklands War. ${ }^{124}$ There are, however, crucial

117 Ibid.

118 Questions relating to the Seizure and Detention of Certain Documents and Data (TimorLeste $v$ Australia), Institution of Proceedings, 17 December 2013, General List No 156 [2013] ICJ 1 .

119 With the chutzpah which characterizes much Australian Government commentary in this context, then Prime Minister Tony Abbott said (in the context of leaks suggesting Australia had spied on Indonesian officials engaged in trade talks over prawn exports): 'We use surveillance ... to protect our citizens ... we certainly don't do it for commercial purposes' (quoted, K McGrath, 'Oil, Gas and Spy Games in the Timor Sea' The Monthly, (April 2014) 4).

120 Questions relating to the Seizure and Detention of Certain Documents and Data (TimorLeste v. Australia), Provisional Measures, Order of 3 March 2014, (2014) ICJ Reports, p 147.

121 Questions relating to the Seizure and Detention of Certain Documents and Data (TimorLeste v. Australia), Discontinuance, Order of 11 June 2015, (2015) ICJ Reports, p 572.

122 A Mitchell 'Spies, Lies and Timor Gas: Prepare to be Rocked by Canberra Lawyer's Book' New Matilda (9 February 2018); B Collaery, Oil Under Troubled Water (Melbourne University Press, 2020).

123 M Turnbull, The Spycatcher Trial (Heinemann, 1988).

124 C Ponting, The Right to Know (Sphere Books, 1985). 
differences: Collaery and Witness $\mathrm{K}$ are to be represented by security-vetted lawyers, and apparently to be tried without a jury, in secret proceedings. ${ }^{125}$ Comparisons with another defendant known only as K are irresistible. ${ }^{126}$

\section{Development Diseconomics}

Both Australia and the oil companies have enjoyed a great advantage in negotiating with Timor-Leste: they know that Timor-Leste cannot afford a significant delay because its economic position is precarious. Moreover, 9o percent of Timor-Leste's State budget and 70 percent of total GDP has relied on finite revenue from the JPDA. ${ }^{127}$ It has been invested in a sovereign wealth fund which 'has significantly encouraged social and economic development since $2005 \cdot{ }^{128}$ The World Bank reports that in the decade following 2005, Timor-Leste 'made good progress in alleviating poverty and the benefits of public investment are becoming evident with sharply improved access to electricity and significant improvement in other basic infrastructure services.' ${ }^{29}$ However, Timor-Leste remains in the UN's category of Least Developed Countries: 'Poverty remains persistently high, particularly in rural areas, where the majority of the population lives. Nearly half of the population is estimated to live below the national poverty line of US\$o.88 per day.'130

The World Bank put it bluntly: 'oil production is ceasing, leaving a large fiscal deficit and a depleting sovereign fund'. It estimated that oil production 'may have fallen by as much as 50\% in 2016', while oil revenue fell by 60 percent. The budget ran into deficit, with 'the government running down its financial

125 D Dixon, 'Political Trials: From Clive Ponting to Bernard Collaery and Witness K', [2020] UNSW Law Research Paper No. 72; see also Fernandes, above (n 112); Collaery, above (n 96); B Collaery, 'Who is Watching the Watchers? A Quest for Rule of Law in a World of Relentless Secret Intelligence Surveillance' (2014), ntba.asn.au/wp-content/uploads/ Supplementary-Paper-2.docx; accessed 1 July 2018; S Cannane, S Koloff and B Andersen, “ "Matter of Life and Death": Espionage in East Timor and Australia's Diplomatic Bungle' $A B C$ News (26 November 2015), http://www.abc.net.au/news/2015-11-25/east-timorgreater-sunrise-spy-scandal/6969830; accessed 1 July 2018.

126 F Kafka, The Trial (Victor Gollancz, 1935).

127 B Strating, 'What's Behind Timor-Leste's Approach to Solving the Timor Sea Dispute?' The Conversation (19 April 2016).

128 мво, above (n 19), 14.

129 World Bank, 'Timor-Leste' in East Asia and Pacific Economic Update (World Bank, 2017) 164-167, 166.

13 мво, above (n 19), 14. 
assets.'131 For the Timor-Leste Government, further development depends on continuing revenue from resource exploitation. This reliance is unsustainable unless Greater Sunrise is exploited because the 'Bayu-Undan field will stop producing in 2022 and the US\$16 billion sovereign wealth fund could be depleted by $2025 .{ }^{132}$ At stake in Greater Sunrise are reserves now thought to be worth twice that estimated a decade ago: 5.13 trillion cubic feet of gas and 225.9 million barrels of condensate worth some A $\$ 4$ o billion. ${ }^{133}$ However, the World Bank reports that 'The prospect of new oil fields being exploited in Timor-Leste remains highly uncertain ... Even if viable fields were developed (this) is unlikely to happen for 10 years.'. ${ }^{134}$

Woodside led a commercial joint venture which included Royal Dutch Shell, ConocoPhilips and Osaka Gas. In 2015, Woodside suspended further preparatory work on Greater Sunrise until boundary and processing issues were resolved. This announcement was intended to put pressure on the TimorLeste government to agree to continue the CMATS agreement without establishing a maritime boundary and to installing a floating liquefied natural gas (FLNG) plant rather than on-shore processing. From the resource companies' perspective, the decline in oil and gas prices reduced short-term pressure to get Greater Sunrise operational, and encouraged them to play hard-ball with Timor-Leste. ${ }^{135}$

\section{Processing Proceeds}

While Timor-Leste's public rhetoric focused on the maritime boundary, a quite different technical operational question was of equal significance and complexity: where should the output from Greater Sunrise be processed - in Timor-Leste, in Australia, or at sea on a FLNG facility? What was at stake had been demonstrated by the benefits (including several thousand jobs) which the Bayu-Undan pipeline brought to Australia's Northern Territory. Having been forced to accept this as a cost of cMATs, Timor-Leste was determined not to

\footnotetext{
131 World Bank, above (n 129), 164-165; see also Cleary, above (n 30 ).

132 Strating, above (n 127); see also D Evans, 'Time Ticking for Timor-Leste as Sunrise Shelved' Petroleum Economist (19 March 2015).

133 JSCT, above (n 88), para 2.11.

134 World Bank, above (n 129), 166.

135 E Stewart, 'Woodside Petroleum Waiting on Australia -East Timor Maritime Deal to Develop Greater Sunrise' ABC News (10 January 2017), http://www.abc.net.au/news/2017o1-11/woodside-petroleum-interview/8174854; accessed 1 July 2018.
} 
lose out again. ${ }^{136}$ The Timor-Leste Government refused to approve any development plan for Greater Sunrise, which did not include piping to a processing facility on Timor's south coast. ${ }^{137}$ In optimistic anticipation of winning the case for on-shore processing, Timor-Leste invested heavily in 'mega-projects and large-scale infrastructure spending', ${ }^{138}$ notably the Tasi Mane Project, 'the flagship programme of Timor-Leste's development strategy',139 which involves three petro-chemical industrial clusters on Timor-Leste's south coast.

Timor-Leste's problem is that while borders and boundaries can be agreed by governments, operational decisions are made by corporations seeking the most commercially favourable option. For a time, there was considerable friction between Timor-Leste and Woodside, whose chief executive Don Voelte stated that the pipeline would go to Timor-Leste 'over my dead body'. Woodside's adversarial and disparaging treatment of Timor-Leste in this period has been strongly criticized by a former Woodside employee. ${ }^{140}$ A greater obstacle than Voelte's body was the 3000 metre Timor Trough which a pipe to Timor-Leste would have to cross before landfall. Objections that doing so would be either impossible or prohibitively expensive ${ }^{141}$ were countered by claims that it can be done technically and economically enough to meet the commercial standard required. ${ }^{142}$

At this stage, Woodside favoured a FLNG facility on which gas would be 'processed, liquefied and stored ... before being loaded onto tankers and exported' directly to consuming countries. ${ }^{143}$ Shell, one of Woodside's then partners in the Greater Sunrise Joint Venture, was committed to FLNG which had been 'touted as the solution to the soaring development costs now blighting the next wave of LNG investment in Australia.. ${ }^{144}$ However, enthusiasm for FLNG has declined so rapidly following substantial delays and budget blow-outs in

136 Strating, above (n 127), 26o-262.

137 La'o Hamutuk, 'The Greater Sunrise Oil and Gas Project' (17 April 2015), http://www.laohamutuk.org/Oil/Sunrise/1oSunrise.htm; accessed 1 July 2018.

138 M Leach, 'A Line in the Water' Inside Story (12 January 2017).

139 M Palatino, 'Timor-Leste's Tasi Mane Project' The Diplomat (17 October 2011); see also Cleary, above (n 30) and the sources listed at https://www.laohamutuk.org/Oil/OilIndex. html\#TasiMane; accessed 1 July 2018. See the Timor Leste Strategic Development Plan 20112030, above (n 82).

140 M Whyte, 'Cowboys, Ogres and Donors: A Decade of CSR in Practice - New Zealand, Australia, Timor-Leste and Indonesia' (2011), https://www.laohamutuk.org/Oil/Sunrise/ 2011/WhyteCSRMay2011.pdf; accessed 3o Sept 2020.

141 D Evans, 'The Great Game of Greater Sunrise' Petroleum Economist, (October 2011).

142 Brennan, above (n 89), 56; Collaery above (n 96), 34-5.

143 King, above (n 20), 49.

144 D Evans, 'FLNG: Charting a New Course' Petroleum Economist (8 July 2014). 
Shell's Prelude project, an enormous FLNG facility off Western Australia, ${ }^{145}$ that FLNG has dropped out of contention. This left use of Darwin, where another of Woodside's then partners, ConocoPhillips, operates a facility for product piped from Bayu-Undan which, with the depletion of that field, will soon be in need of new supply. By 2018, the Conciliation Commission could report that the 'Joint Venture have consistently held the view that only DarwinLNG is commercially viable. ${ }^{\prime 46}$

The 2018 Treaty includes provisions designed to encourage Timor-Leste to accept processing in Australia. If output is not piped to Timor-Leste, its share of the upstream revenue would increase from 70 to 80 percent and there are local content commitments to improve Timor-Leste's workforce and industrial capacity. ${ }^{147}$ The Conciliation Commission did not resolve this matter of where output should be processed: 'this is less a bilateral negotiation between Australia and Timor Leste, and more a complex multiparty negotiations between these states and a consortium of oil companies.'148 However, it did engage independent assessors of the choice between Timor-Leste and Darwin. While their report did not make recommendations, its conclusion was clear: processing on Timor-Leste would only be commercially viable if Timor-Leste subsidized it by an extraordinary allocation of funds which it would have to access from international investors. ${ }^{149}$ Again, measures to encourage Timor-Leste to accept Darwin LNG were included. The Joint Venture had committed to locating support operations for the Greater Sunrise Project in Timor-Leste and providing 'funding for a domestic gas pipeline to Timor-Leste which could be used for power generation, industrial development, and petrochemicals, for the benefit of the Timorese people' supplying gas at 'gas transfer price', as well as a range of other commercial, employment, education and investment incentives. ${ }^{150}$

Xanana Gusmão had become strongly committed to piping output to a south coast hub, claiming that it is 'non-negotiable'.151 He responded angrily and sarcastically to the Commission's paper, challenging the good faith of the

\footnotetext{
145 P Klinger, 'Delays Slow Prelude's Sail-away' The West Australian (12 April 2016).

146 Annex 27: Commission Paper on the Comparative Development Benefits of Timor-LNG and Darwin-LNG, 9 May 2018, PCA Case No 2016-10, 4.

147 Above (n 1), Annex B, Arts 2, 14.

148 Schofield and Strating, above (n 93).

149 Annex 27, above (n 146).

15 O Ibid 2-3. This time, crossing the Timor Trough is apparently unproblematic.

151 Quoted in R Strating and C Schofield, 'Australia's Deal with Timor-Leste in Peril Again over Oil and Gas' The Conversation (25 May 2018).
} 
Conciliation Commission, Australia and the commercial venture partners. ${ }^{152}$ Elections in May 2018 left Gusmão as the apparently dominant force in TimorLeste's domestic politics, despite Prime Minister Taur Matan Ruak's Popular Liberation Party's criticism of big infrastructure projects and dependence on oil. ${ }^{153}$ Timor LNG is now as politically significant as the maritime boundary. At the time of writing, Timor-Leste may have achieved delineation of its maritime boundaries, but it seems no closer to getting the economic benefits on which its future has been staked. ${ }^{154}$ While its Strategic Development Plan aims for 'a sustainable and diversified non-oil economy' by 2030 and a 'modern diversified economy', it still looks to 'the petroleum sector to 'provide an industrial base to our economy' and to remain 'a key pillar of our future development'. ${ }^{155}$

Opinion on the location of processing is not uniform in Timor-Leste, with the ever-pragmatic José Ramos-Horta expressing scepticism about the Government's attitude: 'We must be the only country in the world that has organised demonstrations against international investors.' ${ }^{156}$ One view is that Timor-Leste should focus not on on-shore processing, but on a deal of the kind offered to access 'all the LNG gas it needs for electricity generation and industrial feedstock, and supply the entire domestic market for household LPG' so providing the power supply to encourage other economic activity. ${ }^{157}$ This finds some support from critics of the Timor-Leste Government's investment in the south coast development who say Timor-Leste should diversify its economy, reducing dependence on oil and gas. ${ }^{158}$ The World Bank, 'after years of echoing the government's petroleum-dominated priorities, highlighted the need for non-petroleum economic development in its 2013-2017 Country Partnership Strategy'. ${ }^{159}$ The World Bank insists that the 'overriding fiscal challenge for

152 In reference to a letter to the Commission dated 28 February 2018, see P Lloyd, 'East Timor Accuses Australia of Colluding with Companies over Greater Sunrise Oil and Gas Deal' $A B C$ News (6 March 2018), http://www.abc.net.au/news/2018-o3-o6/east-timor-acusesaustralia-of-collusion/9519530 (accessed 1 July 2018).

153 S Ingram, 'Rough Ride Ahead? Leading Timor-Leste's Coalition Government' Australian Outlook (28 June 2018).

154 Strating, above (n 127), 270.

155 Timor-Leste Strategic Development Plan 2011-2030, above (n 82), 106, 136.

156 Quoted in La'o Hamutuk, above (n 137), 11.

157 H McDonald, 'It's Tiny, Poor, and Very Possibly Not Going to Take it Anymore' The Global Mail (28 March 2013); see also Evans, above (n 141), 3.

158 Scheiner, quoted in McDonald, above (n 157), 6; Strating, above (n 62), 265-266.

159 Evans, above ( $\mathrm{n} \mathrm{132}$ ). The best-informed and most sophisticated investigation of the issues is G Neves, C Sheiner and S Soares, Sunrise LNH in Timor-Leste: Dreams, Realities and Challenges (La'o Hamutuk, 2008). See also La'o Hamutuk, 'The Timor-Leste-Australia Maritime Boundary Treaty' (21 March 2018), https://www.laohamutuk.org/Oil/Boundary/ Treaty/18TreatyArticleEn.htm; accessed 30 September 2020. 
Timor-Leste is transition to a more sustainable model and rebalancing towards private-sector-led growth. ${ }^{\prime 60}$ Other commentators have argued that local benefits of LNG should not be overstated, especially given the limited capacity of Timor-Leste to supply material and skilled workers. ${ }^{161}$ Most tellingly, similar arguments are made from within Timor-Leste by the impressively well-informed NGO, La'o Hamutuk: 'For more than a decade, the think tank and others in civil society have encouraged the government to cut its dependency on petroleum income and steer a more sustainable course.' ${ }^{162}$ Almost inevitably, the phrase 'resource curse' is applied by the Government's critics. ${ }^{163}$ Most commentators agree that, whatever happens, it will not happen quickly, and delay may be very costly to Timor-Leste. The Conciliation Commission commented bluntly in its paper on processing that 'the benefits of developing Greater Sunrise will only be realized if the field is in fact developed.' ${ }^{164}$ That depends on not just nations, but also investors and commercial operators, agreeing to do so.

In 2018-19, there was a crucial change in the Greater Sunrise Joint Venture. Timor-Leste bought out ConocoPhillips and Shell, giving it a 56.56 percent share. Woodside became a minority shareholder holding 33.44 percent, with Osaka Gas holding the remaining 10 percent. The cost was massive for TimorLeste. ${ }^{165}$ As noted above, ConocoPhillips is 'the principal owner of the soonto-be-idle LNG plant' in Darwin: not surprisingly, it strongly favoured onshore processing there. ${ }^{166}$ By taking ConocoPhillips' and Shell's seats at the

16o World Bank, 'Timor-Leste' in East Asia and Pacific Economic Update (April 2017) 164-167, 166, http://pubdocs.worldbank.org/en/446651493090553126/Timor-Leste-Econ-UpdateApril-2017-EN.pdf; accessed 4 July 2019.

161 Evans, above (n 132).

162 Ibid.

163 See La'o Hamutuk, 'Index to Articles about Oil and Gas', https://www.laohamutuk.org/ Oil/OilIndex.html\#TasiMane (accessed 1 July 2018); see also, Strating, above (n 62), 265; J Drysdale, 'Five Principles for the Management of Natural Resource Revenue' (2008) 26 Journal of Energy \& Natural Resources Law 151-174.

164 Annex 27, above (n 146), 4.

165 Timor-Leste paid Conoco Phillips and Shell US $\$ 35^{\circ}$ million for their shares: See ConocoPhillips and Government of Timor-Leste agree on terms for sale of interest in Greater Sunrise Fields, available at: http://timor-leste.gov.tl/?p=20613\&lang=en, accessed 30 September 2020; P Williams, 'Woodside Considers Options as ConocoPhillips Sells Sunrise LNG to East Timor Government' The West Australian (2 October 2018); H Davidson, 'Timor-Leste Rejects Report it is Taking \$16bn Loan from China's Exim Bank for Gas Project' The Guardian (26 June 2019).

166 La'o Hamutuk, 'Timor-Leste Buys into the Sunrise Oil and Gas Project' (1o August 2020), http://laohamutuk.org/Oil/Sunrise/18SunriseBuyout.htm\#: :text=On\%2O28\%20 September\%2C\%2onegotiators\%2ofrom,Woodside\%2C\%2oShell\%2oand\%2o Osaka\%2oGas; accessed 30 September 2020. 
table, Timor-Leste has been able to push for on-shore processing in Timor. In mid-2019, the re-constituted Joint Venture began discussions on technical studies and economic models. While Woodside, after years of opposition, has accepted this and supports TLNG, this radical change has a catch: Woodside has made it clear that it will not invest in processing on Timor. ${ }^{167}$ This leaves Timor-Leste needing some US $\$ 18$ billion to provide further infrastructure for a project which will not be profitable for several years. The dilemma looks likely to be resolved by investment from China, ${ }^{168}$ inevitably raising concerns about China's political and military expansion. ${ }^{169}$

Timor-Leste faces a real dilemma. The leadership has made much of the sovereignty principle, linking both the maritime boundary and on-shore processing to the completion of Timor-Leste's independence. ${ }^{170}$ La'o Hamutuk $^{\prime}$ described the drawing of maritime boundaries as ending 'one of the last remnants of Indonesia's illegal occupation of Timor-Leste: Australia's continued occupation of significant parts of our maritime territory'. ${ }^{171}$ However, La'o Hamutuk also warns about the cost and uncertainty of TLNG and its diversion of attention and resources from other options. As Australian commentators note, " $[t]$ he issue of the boundaries as a matter of sovereignty, while symbolically important, is a distraction from the core consideration. What really matters for Timor-Leste's sovereignty and its economic viability is a quick resolution on the pipeline, leading to a swift development of the fields.'.172 Xanana Gusmão appears to have tied his continuing political ascendancy to TLNG, expecting the kind of faith in him which sustained the resistance against Indonesian occupation. However, his flippancy may not encourage confidence: 'In response to those who question the cost or feasibility of the project, the Chief Negotiator said “I don't care" and encouraged viewers to trust that "I will win" and prove the naysayers wrong, as he did in the struggle for

167 R Searancke, 'FPSO takes centre stage at Sunrise development' Upstream (7 May 2019), https://www.laohamutuk.org/Oil/Sunrise/2019/UpstreamFPSOSunrise7May2019.pdf; accessed 5 July 2019.

168 M Sainsbury, 'East Timor Buys ConocoPhillips' Greater Sunrise Share for \$484m' Australian Financial Review (3o September 2018); A Macdonald-Smith, 'Timor-Leste Sees China as Option for LNG Capital' Australian Financial Review (12 March 2019).

169 A Dupont, 'Australia Must Not Lose East Timor to China' The Australian (2 July 2019); B Packham, 'Timor Debt Could Open Door to China Navy' The Australian (25 June 2019).

170 Schofield and Strating, above (n 93).

171 La'o Hamutuk, 'Submission to the Australian Parliament Joint Standing Committee on Treaties' (18 April 2018) 3, http://www.laohamutuk.org/Oil/Boundary/JSCT/2018/ LHtoJSCT18Apr2o18.pdf; accessed 1 July 2018.

172 Schofield and Strating, above (n 93), 4. 
Timor-Leste's independence.'173 Papua New Guinea's experience with LNG-led development is certainly not encouraging. ${ }^{174}$ If the new maritime boundary does not lead to Timor-Leste's promised economic recovery, the domestic political and social consequences could be very problematic.

\section{3}

\section{Kangaroos and Crocodiles}

The Timor Sea dispute is far from over. Australia has done very well out of it so far, retaining the proceeds of fields now acknowledged to be within TimorLeste's maritime boundaries which are secured from any claim for compensation, ${ }^{175}$ negotiating a treaty allocating it one-third of the Greater Sunrise area, at least 20 percent of the Sunrise proceeds, and claiming the high ground of international legality in criticizing China's actions in the South China Sea. ${ }^{176}$ Extending its record of prioritizing self-interest, Australia delayed ratifying the Treaty for more than one year, allowing it to continue taking proceeds from Bayu-Udan. ${ }^{177}$ Portugal and Indonesia are disengaged, although the latter has interests, in both boundaries and resources, which remain uncertain. ${ }^{178}$ Timor-Leste may have won a symbolic victory in establishing its sovereignty by negotiating a maritime boundary on the median line, but such boundaries may prove to be less significant than economic divisions. Meanwhile, Australia moves on without acknowledging how its treatment of a vulnerable neighbour has crossed borders of honesty, decency and morality.

173 La'o Hamutuk, above (n 166).

174 Jubilee Australia, Double or Nothing: The Broken Economic Promises of PNG LNG (Jubilee Australia Research Centre, 2018); On Shaky Ground: PNG LNG and the Consequences of Development Failure (Jubilee Australia Research Centre, 2018).

1752018 Treaty, above (n 1), Art 10.

176 T Clarke, 'Australia as Guilty as China' Sydney Morning Herald (15 July 2016) 17.

177 H Davidson, 'Australia Accused of "Siphoning" Millions in Timor-Leste Oil Revenue' The Guardian (15 April 2019); S Raynor, 'Timor-Leste's Missing Oil Millions' (5 June 2019) 29(11) Eureka Street.

${ }_{178}$ See above (n 93). 